\title{
Corruption in Malaysia: A Review
}

\author{
Shankar Durairaja ${ }^{1}$, Geshina Ayu Mat Saat ${ }^{1 *}$, Mohammad Rahim Kamaluddin' ${ }^{2}$, Nagentheraan \\ Munesveran' ${ }^{1}$ Asilah Hassunna Azmi' and Ler Lien Jia ${ }^{1}$
}

\author{
'Forensic Science Programme, School of Health Sciences, Health Campus,UniversitiSains Malaysia, Malaysia; \\ durairajashankar@gmail.com, geshinaayu@yahoo.co.uk,nagen_0912@hotmail.com, \\ asilahhassunna96@gmail.com, lerlienjia.lj@gmail.com \\ ${ }^{2}$ Psychology and Human Well-being Research Centre, Faculty of Social Sciences and Humanities, \\ Universiti Kebangsaan Malaysia, Malaysia; rahimk@ukm.edu.my
}

\begin{abstract}
Objective: This study presents a review of the studies on corruption in Malaysia that have been conducted from different approaches. Methodology: A literature search was done in the English language relating to corruption and its related terminologies. Google Scholar, Science Direct, Wiley Online Library, and SAGE are the four data sources that were selected to conduct the literature search. Fifteen papers met the predetermined criteria. The selected online published materials were between the years 2000 and 2017. Only expert opinion materials, editorials, reports, reviews, and grey literature were considered for this review. Findings: As a result of this review, many studies discussed the various government initiated anti-corruption actions over the past decades; several studies criticized the failures and limitations of the government's anti-corruption actions, while some postulated the reasons behind corruption. One study surmised the problems in the judicial system when handling bribery and corruption cases. Conclusion: Gaps identified from these studies suggest a need for researches focusing on psychological and criminological aspects of corruption as roots of the problem. In addition, focusing on psychological and criminological aspects of corruption can become foundations for effective and proactive community crime prevention measures that can be implemented by policy makers, and governments and non-government agencies.
\end{abstract}

Keywords: Anti-Corruption, Bribe, Corruption, Review

\section{Introduction}

Over the decades, Malaysia has encountered many corruption cases involving renowned politicians, government officials, private and government company executives, white collar professionals, blue collar workers, and the normal public. Examples include the Bumiputra Malaysia Finance scandal in 1983, Pan-Electric Industries scandal in 1985, Deposit-taking co-operative scandal in 1986, Perwaja Steel scandal in 1980s, Maminco-Makuwasa scandal in 1980s, Forex scandal in 1992-1993, Malaysian Airlines (MAS) financial scandal in 1994-2001, Port Klang Free Zone (PKFZ) scandal in 2007-2008, National Feedlot Corporation (NFC) scandal in 2010, 1Malaysia Development Bhd (1MDB) scandal in 2010, and the Felda Global Ventures scandal in 2017. Seizures of millions of ringgits from prominent government and non-government officials make the public question whether the ini- tiatives taken by the government to curb corruption is effective or practical.

More recently, Transparency International claimed Malaysia scored 47 points on the 2017 Corruption Perception Index ${ }^{1}$. Malaysia's position dropped seven places in the overall ranking of 180 countries to $62 \mathrm{nd}$ place, the country's lowest position since the index was started in 1995 (Ibid). This index is based on the perceived levels of public sector corruption according to experts and business people (Ibid). The scale of this index is 0 to 100 , where 0 is highly corrupt and 100 is very clean (Ibid).

Since 2014, Malaysia's score has been dropping every year. In 2014, Malaysia was ranked 51 among 174 countries, with a score of 52, while in 2015; Malaysia was ranked 54 among 168 countries, with a score of 50. In 2016, Malaysia has scored 49 points down one place in the overall ranking of 176 countries to 55th place. Malaysia was ranked 62 among 180 countries in 2017, with a score 
of 47. This is despite many aggressive enforcement actions being carried out against corruption by Malaysian AntiCorruption Commission (MACC) over the past few years ${ }^{2}$. Malaysia's failure to resolve major corruption cases is one of the reason behind the country's poor performance in the Corruption Perception Index.

According to Nur and Nafsiah ${ }^{3}$, in Malaysia, the word "gratification" is commonly used instead of "corruption". The MACC, defines corruption as "the act of giving or receiving of any gratification or reward in the form of cash or in-kind of high value for performing a task in relation to his/her job description"4. According to the MACC Act 2009 (Act 694), corruption can be classified into four main offences: soliciting/receiving gratification (bribe), offering/giving gratification (bribe), intending to deceive (false claim), and using office or position for gratification (bribe) (abuse of power or position).

Bribe can be defined as money or favour given or promised in order to induce or influence the judgment or conduct of a person in a position of trust ${ }^{5}$. Bribe can be in many forms such as money, reward, wage, vote, services, bonus, position, or bonus ${ }^{4}$. Frei and Muethel ${ }^{6}$ asserted that various parties in the private and public arena can practice bribery, suggesting that this form of corruption, at least, is not limited to the organisational setting.
False claim can be explained as an untruthful statement or claim by a person to obtain any kind of benefit or reward ${ }^{7}$. False claims can occur in a variety of industries including healthcare, pharmaceutical, education, financial, and government agencies (Ibid). Amongst the most recent Malaysian case of false claims was reported by the media on April 16,2018, with the trial of a former senior officer of the Youth and Sports Ministry facing 32 charges of misusing his position and submitting false claims involving RM38.4 million ${ }^{8}$.

Based on published statistics the total number of arrests related to corruption between 2011 and 2018 were 6,229 persons, involving both public officers and civilians. Referring to Figure 1, the trend analysis of people arrested from 2011 to 2018 was in a fluctuating pattern. The highest number of arrests was recorded in 2016 with 936 persons followed by the year 2011 with 918 persons. The number of arrests showed a decline from the year 2011, and then increased gradually from the year 2014 . The number of arrests dropped from 936 persons in 2016 to 879 persons in 2017.

Overall, 43.7\% ( $\mathrm{N}=2698)$ of arrested persons were public official and 56.7\% (3532) were civilians. Specifically, the arrested public officials comprised of $72.9 \%(\mathrm{~N}=1968)$ support staffs, followed by $25.3 \%(\mathrm{~N}=683)$ professional

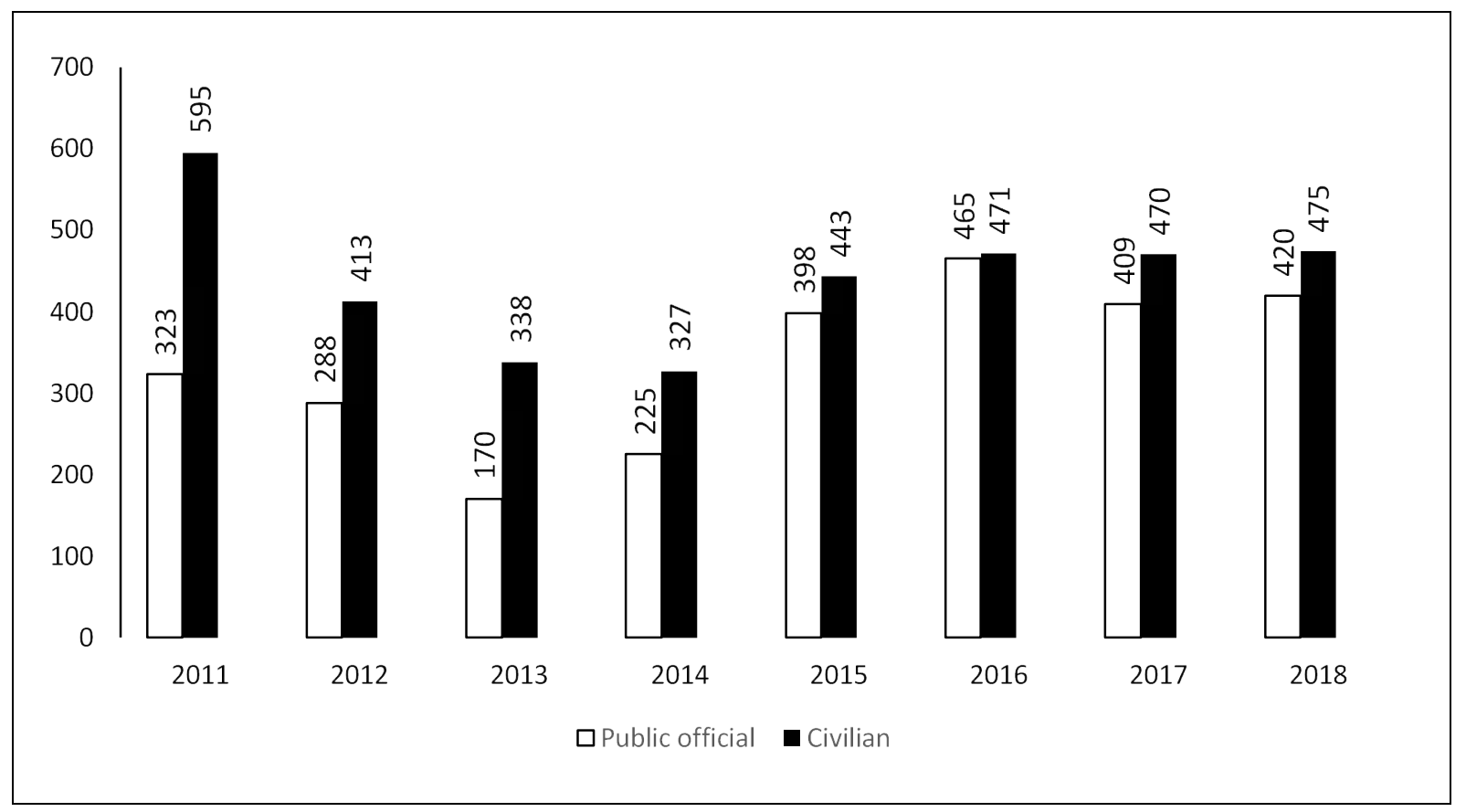

Figure 1. Statistics on arrest (Adapted from MACC ${ }^{4}$ ). 
and management personnel, and $1.5 \%(\mathrm{~N}=47)$ top management personnel. The arrested civilians included $64.4 \%$ $(\mathrm{N}=2273)$ of the general public, 32.2\% $(\mathrm{N}=1139)$ private sector employees, and $3.4 \%(\mathrm{~N}=120)$ local councillors and politicians. From this data, support staffs and the general public were the highest numbers of arrested persons by MACC while politicians and local councillors represented a small percentage.

This is contrary to the public perception of government personnel being the most corrupted compared to other occupational groups. The Global Corruption Barometer - Asia Pacific Region 2017 indicated that the police (57\%) was the most corrupt body in Malaysia, followed by the tax officials (48\%) and local government councillors (48\%), business executives (46\%), government officials $(45 \%)$, the prime minister and officials in his office (41\%) and representatives in the legislature (41\%), judges and magistrates (33\%), and the religious leaders $(31 \%)^{9}$. This is perhaps due to the newsworthy status of the politicians themselves who had abused their positions. It is also likely that the large monetary value of gratification or bribery linked to the politicians were more compared to the gratification or bribery linked to members of the public.

Several Malaysian scholars have explored this topic and provided some valuable outcomes, however what is known about corruption in Malaysia is sporadic. This study presents a review to draw together the disparate literature in order to provide a better understanding of corruption and identify the gaps in knowledge. Further, this review provides a framework and background knowledge to readers in order to plan and execute new research activities.

\section{Method}

\subsection{Data Sources}

Four specific databases were used to perform a systematic search. The databases were Google Scholar, Science Direct, Wiley Online Library, and SAGE. The time frame for the online published materials was between the years 2000 and 2017.

\subsection{Inclusion and Exclusion Criteria}

Specific inclusion and exclusion criteria were used to determine the set mining and association rule for the data extraction. These criteria were developed based on the literature review that was carried out to identify common search parameters. The criteria are listed below.

Studies were included if they fulfilled the following criteria:

1. The selected materials and collected data must be from Malaysia.

2. All selected materials must be in English or Malay.

3. The materials may be expert opinion materials, editorials, reports, reviews, and grey literature.

4. Must be published between January 2000 and December 2017.

5. The population samples are focused on Malaysians.

Studies were excluded if they fulfilled the following criteria:

1. Unavailability of the full text.

2. Materials published other than in English or Malay languages.

3. Materials found to be duplicated.

4. Materials were not peer-reviewed.

\subsection{Data Extraction Methods}

Data extraction is important to ease synthesis and coherent presentation of data by summarizing studies in a common format ${ }^{10}$.

Secondly, it can also recognize numerical data for meta-analyses. Next, data extraction plays a major role in gathering information to measure more quantitatively the risk of bias and applicability of studies (Ibid). Lastly, data extraction can be used to determine systematically missing or incorrectly calculated data, unstudied outcomes, and underrepresented populations (Ibid). In this review, three levels of data extraction were used to filter the variables of interest in order to identify the materials that were related to corruption in Malaysia. Table 1 shows the three data extraction levels.

At the first extraction level, four online databases were used to obtain related materials. Four primary keywords and four secondary keywords were used interchangeably in the literature. Across the databases, 3,084,845 results were identified. Table 2 shows the results of the search in the first extraction level. 
Table 1. The three data extraction levels

\begin{tabular}{|l|l|}
\hline \multirow{2}{*}{ Level One } & $\begin{array}{l}\text { Inclusion criteria } \\
\text { Primary keywords: corruption, combating corruption, effects of corruption, and reasons behind corruption. } \\
\text { Secondary keywords: corruption in Malaysia, combating corruption in Malaysia, effects of corruption in } \\
\text { Malaysia, and reasons behind corruption in Malaysia }\end{array}$ \\
\hline Level Two & $\begin{array}{l}\text { Exclusion criteria } \\
\text { Exclude the literatures that are not related to corruption in Malaysia. }\end{array}$ \\
\hline \multirow{2}{*}{ Level There } & $\begin{array}{l}\text { Inclusion criteria } \\
\text { 1. The selected materials and collected data must be from Malaysia. } \\
\text { 2. All selected materials must be in English or Malay. } \\
\text { 3. The materials may be expert opinion materials, editorials, reports, reviews, and grey literature. } \\
\text { 4. Must be published between January } 2000 \text { and December 2017. } \\
\text { Exclusion criteria samples are focused on Malaysians. } \\
\text { 1. Unavailability of the full text. } \\
\text { 2. Materials published other than in English or Malay languages. } \\
\text { 3. Materials found to be duplicated. } \\
\text { 4. Materials were not peer-reviewed }\end{array}$ \\
\hline
\end{tabular}

Table 2. The results of the search in the first extraction level

\begin{tabular}{|c|c|c|c|c|c|}
\hline Keywords & Google Scholar & Science Direct & Wiley Online Library & SAGE & Total \\
\hline \multicolumn{6}{|l|}{ Primary Keyword } \\
\hline $\begin{array}{l}\text { Corruption } \\
\text { Combating corruption } \\
\text { Effects of corruption } \\
\text { Reasons behind corruption }\end{array}$ & $\begin{array}{l}1,130,000 \\
51,100 \\
1,080,000 \\
418,000\end{array}$ & $\begin{array}{l}29,091 \\
2,818 \\
17,804 \\
7,139\end{array}$ & $\begin{array}{l}45,012 \\
6,432 \\
35,886 \\
13,480\end{array}$ & $\begin{array}{l}34,563 \\
5,713 \\
27,866 \\
11,775\end{array}$ & $\begin{array}{l}1,238,666 \\
66,063 \\
1,161,556 \\
450,394 \\
\end{array}$ \\
\hline \multicolumn{6}{|l|}{ Secondary Keyword } \\
\hline $\begin{array}{l}\text { Corruption in Malaysia } \\
\text { Combating corruption in Malaysia } \\
\text { Effects of corruption in Malaysia } \\
\text { Reasons behind corruption in } \\
\text { Malaysia }\end{array}$ & $\begin{array}{l}83,700 \\
16,100 \\
27,300 \\
20,500 \\
\end{array}$ & $\begin{array}{l}3,071 \\
390 \\
2,359 \\
899 \\
\end{array}$ & $\begin{array}{l}3,099 \\
728 \\
2,798 \\
1,377 \\
\end{array}$ & $\begin{array}{l}2,218 \\
629 \\
1,960 \\
1,038\end{array}$ & $\begin{array}{l}92,088 \\
17,847 \\
34,417 \\
23,814 \\
\end{array}$ \\
\hline \multicolumn{5}{|l|}{ Total } & $3,084,845$ \\
\hline
\end{tabular}

Following from the first extraction level, all the identified materials were filtered in compliance to the exclusion criteria for the second extraction level (Table 1). This resulted in the selection of only 55 materials. These 55 materials were closely related to the primary and secondary keywords. Considering the predetermined criteria for materials (Table 1) to be selected and included in the analysis, only 15 materials were suitable at the end of the third extraction level. In other words, 40 of the 55 materials were excluded from this review. Table 3 shows the materials reviewed.

\section{Findings}

\subsection{Design and Method of Reviewed}

\section{Literature}

Various methods have been used by the authors of the literature reviewed. The methods are divided into quantitative, qualitative, mixed-method (quantitative and qualitative), and perspective, commentary or opinion. Questionnaire, semi-structured and in-depth interview, and documentation methods were adopted by various authors to perform data collection in their respective 
Table 3. Materials included in the review

\begin{tabular}{|c|c|c|c|c|c|}
\hline Study & Setting & Design/ Method & $\begin{array}{l}\text { Focus/ } \\
\text { Instrument }\end{array}$ & $\begin{array}{l}\text { Participants \& } \\
\text { Sample Size }\end{array}$ & Outcomes \\
\hline $\operatorname{In}^{24}$ & $\begin{array}{l}\text { Construction } \\
\text { industry }\end{array}$ & $\begin{array}{l}\text { 1. Exploratory } \\
\text { interviews } \\
\text { 2. Brain-storming } \\
\text { workshop } \\
\text { 3. Questionnaire } \\
\text { survey }\end{array}$ & $\begin{array}{l}\text { Questionnaire } \\
\text { and interview }\end{array}$ & $\begin{array}{l}\text { Government, } \\
\text { public } \\
\text { authorities, } \\
\text { consultants and } \\
\text { contractors ( } \mathrm{N}= \\
124)\end{array}$ & $\begin{array}{l}\text { - } 100 \% \text { of the respondents agreed } \\
\text { that corruption is related to human } \\
\text { behaviours (obedient behaviour of an } \\
\text { individual to follow the law; behaviour } \\
\text { that did not see corruption as a crime; } \\
\text { and negative behaviours of greed, } \\
\text { jealousy, boast and dishonest). } \\
\text { The sources of corruption consist } \\
\text { of five elements: mentality, culture, } \\
\text { environment, lifestyle, and inevitability. } \\
\text { Four significant factors (the desire } \\
\text { to achieve a private or professional } \\
\text { goal by involving in corrupt practices; } \\
\text { subjective norms; Perceived Behavioural } \\
\text { Control and attitude) are positively } \\
\text { related to corrupt acts. }\end{array}$ \\
\hline $\operatorname{In}^{22}$ & Not applicable & $\begin{array}{l}\text { Face-to-face } \\
\text { interviews }\end{array}$ & Interview & $\begin{array}{l}\text { Practitioners, } \\
\text { representatives } \\
\text { from government } \\
\text { agencies and } \\
\text { senior public- } \\
\text { sector officials } \\
(\mathrm{N}=12)\end{array}$ & $\begin{array}{l}\text { Power, opportunity and lack of moral values } \\
\text { are the reasons behind corruption. }\end{array}$ \\
\hline $\operatorname{In}^{12,13}$ & Not applicable & $\begin{array}{l}\text { Commentary/ } \\
\text { opinion article } \\
\text { (Critical } \\
\text { overview) }\end{array}$ & $\begin{array}{l}\text { Literature } \\
\text { review }\end{array}$ & $\begin{array}{l}\text { Published } \\
\text { articles, books, } \\
\text { and reports. }\end{array}$ & $\begin{array}{l}\text { Reasons behind the failures of anti- } \\
\text { corruption strategies and drives: } \\
\text { - } \quad \text { Poor implementation and subsequent } \\
\text { consolidation } \\
\text { - } \quad \text { Low political will to fight corruption } \\
\text { - Deficiencies in the existing institutions } \\
\text { - Defects in the country's political } \\
\text { systems, cultures, and institutions }\end{array}$ \\
\hline $\operatorname{In}^{3}$ & Not applicable & $\begin{array}{l}\text { Commentary/ } \\
\text { opinion article }\end{array}$ & $\begin{array}{l}\text { Literature } \\
\text { review }\end{array}$ & $\begin{array}{l}\text { Published } \\
\text { articles, books, } \\
\text { and reports. }\end{array}$ & $\begin{array}{l}\text { - Corruption reduces the investor's trust, } \\
\text { reduces the productivity of public } \\
\text { expenditures, alters the allocation of } \\
\text { resources and thus lowers the economic } \\
\text { growth of countries. } \\
\text { - } \\
\text { Strategies to curb corruption in } \\
\text { Malaysia have failed to give significant } \\
\text { impacts on corruption. } \\
\text { - The leadership in Malaysia appears to } \\
\text { be efficient in importing new models } \\
\text { but poor in implementation and their } \\
\text { subsequent consolidation. } \\
\text { Deficiencies in the existing institutions } \\
\text { and defects in the country's political } \\
\text { system, cultures and institutions have } \\
\text { undermined the government's anti- } \\
\text { corruption drives to the large extent. }\end{array}$ \\
\hline
\end{tabular}




\begin{tabular}{|c|c|c|c|c|c|}
\hline $\operatorname{In}^{43}$ & $\begin{array}{l}\text { Government } \\
\text { departments }\end{array}$ & Survey & Questionnaire & $\begin{array}{l}\text { Government } \\
\text { servants }(N=596)\end{array}$ & $\begin{array}{l}\text { - Young civil servants are more likely to } \\
\text { involve in corruption } \\
\text { - } \quad \text { Police and immigration departments } \\
\text { have a high probability of corruption } \\
\text { - } \quad \text { Payments of personal debt positively } \\
\text { contribute to the high tendency of } \\
\text { corruption among government servants. }\end{array}$ \\
\hline $\operatorname{In}^{14}$ & Public & Survey & Questionnaire & Public $(\mathrm{N}=1000)$ & $\begin{array}{l}\text { - Present the general public's perspective } \\
\text { on corruption } \\
\text { - Examines public willingness to engage } \\
\text { in the fight against corruption }\end{array}$ \\
\hline $\operatorname{In}^{11}$ & Not applicable & $\begin{array}{l}\text { Commentary/ } \\
\text { opinion article }\end{array}$ & $\begin{array}{l}\text { Literature } \\
\text { review }\end{array}$ & $\begin{array}{l}\text { Published } \\
\text { articles, books, } \\
\text { and reports. }\end{array}$ & $\begin{array}{l}\text { - Anti-corruption drives in Malaysia are not } \\
\text { making any drastic changes. } \\
\text { - Civil society and private sectors need to be } \\
\text { engaged more. } \\
\text { - The established institutions need to be } \\
\text { strengthened with the system of checks } \\
\text { and balance } \\
\text { - The government's political will to combat } \\
\text { corruption need to be demonstrated } \\
\text { and those in power need to change their } \\
\text { mindsets }\end{array}$ \\
\hline $\operatorname{In}^{20}$ & $\begin{array}{l}\text { Law } \\
\text { enforcement } \\
\text { agencies }\end{array}$ & $\begin{array}{l}\text { Semi-structured } \\
\text { interviews }\end{array}$ & Interview & $\begin{array}{l}\text { Law enforcement } \\
\text { officers }(\mathrm{N}=7)\end{array}$ & $\begin{array}{l}\text { Causes of bribery are: influences from } \\
\text { family, public (special interest group, } \\
\text { friends, and acquaintance), individual } \\
\text { (religious faith), and organizational (co- } \\
\text { worker). }\end{array}$ \\
\hline $\mathrm{In}^{21}$ & $\begin{array}{l}\text { Government } \\
\text { officials }\end{array}$ & Survey & Questionnaire & $\begin{array}{l}\text { Independent } \\
\text { Chief Integrity } \\
\text { Officers }(\mathrm{N}=180) \text {. }\end{array}$ & 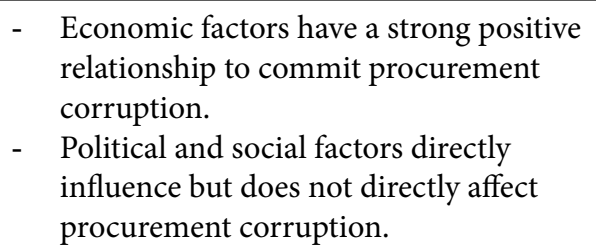 \\
\hline $\operatorname{In}^{23}$ & Public & $\begin{array}{l}\text { 1. Survey } \\
\text { 2. In-depth } \\
\text { interviews } \\
\text { 3. Focus group } \\
\text { discussions }\end{array}$ & $\begin{array}{l}\text { Questionnaire } \\
\text { and interview }\end{array}$ & $\begin{array}{l}\text { General public, } \\
\text { private and } \\
\text { public sector } \\
\text { middle level } \\
\text { employees, } \\
\text { political leaders } \\
\text { and members, } \\
\text { NGO leaders } \\
\text { and members, } \\
\text { and university } \\
\text { students } \\
(\mathrm{N}=7594) .\end{array}$ & $\begin{array}{l}\text { - Majority of the respondents maintain } \\
\text { strong noble values, do not indulge in } \\
\text { corruption, and in fact strongly oppose } \\
\text { it. They are willing to work with ACA to } \\
\text { fight corruption. } \\
\text { - A small segment of the respondents } \\
\text { condone and indulge in corruption and } \\
\text { are not ready to cooperate in the fight } \\
\text { against it. Majority of them were private } \\
\text { sector employees. }\end{array}$ \\
\hline $\operatorname{In}^{16}$ & $\begin{array}{l}\text { Government } \\
\text { agencies, federal } \\
\text { departments, } \\
\text { statutory } \\
\text { bodies, and } \\
\text { government } \\
\text { linked } \\
\text { companies in } \\
\text { Malaysia }\end{array}$ & Survey & Questionnaire & $\begin{array}{l}\text { Integrity Officers } \\
(\mathrm{N}=36)\end{array}$ & $\begin{array}{l}\text { Two of the models (EGM and HGM) } \\
\text { are indicated to have a significant } \\
\text { relationship with corruption risk. } \\
\text { - Three of the models (DGM, ITGM, and } \\
\text { CGM) are proved to have no significant } \\
\text { relationship with corruption risk. } \\
\text { - The result indicates that the relationship } \\
\text { between data governance and } \\
\text { corruption risk is not significant. }\end{array}$ \\
\hline
\end{tabular}




\begin{tabular}{|l|l|l|l|l|l|}
\hline In $^{17}$ & $\begin{array}{l}\text { Undergraduate } \\
\text { students }\end{array}$ & Survey & Questionnaire & $\begin{array}{l}\text { - } \\
\text { Business } \\
\text { undergraduates } \\
(\mathrm{N}=156)\end{array}$ & $\begin{array}{l}\text { Most business undergraduates in } \\
\text { Malaysia support the introduction of an } \\
\text { anti-bribery legislation. } \\
\text { Most business undergraduates are } \\
\text { asserted that employers should be } \\
\text { permitted to accept gifts from outside } \\
\text { agents under certain conditions. }\end{array}$ \\
\hline In $^{21}$ & Court cases & Documentation & Archival data & $\begin{array}{l}\text { Court cases } \\
\text { relating to } \\
\text { bribery and } \\
\text { corruption } \\
\text { (N=1869) }\end{array}$ & $\begin{array}{l}\text { Judges appear to be influenced significantly } \\
\text { by perceptions of the offender's societal and } \\
\text { political position, and power and personal } \\
\text { characteristics in making sentencing } \\
\text { decisions. }\end{array}$ \\
\hline In $^{19}$ & $\begin{array}{l}\text { Government } \\
\text { agencies }\end{array}$ & $\begin{array}{l}\text { 2. Semi-structured } \\
\text { interviews }\end{array}$ & $\begin{array}{l}\text { Archival data. } \\
\text { Interview. }\end{array}$ & $\begin{array}{l}\text { Procurement } \\
\text { officers (N=13) }\end{array}$ & $\begin{array}{l}\text { e-Procurement can: } \\
\text { dispute political and economic forces in } \\
\text { government purchasing processes } \\
\text { manage demands and interference when } \\
\text { rewarding government contracts } \\
\text { be used efficiently at the nexus of } \\
\text { government and businesses. }\end{array}$ \\
\hline
\end{tabular}

studies. Four reviewed articles ${ }^{3,11-13}$ were perspective, commentary or opinion articles which reviewed important topics related to corruption.

Next, five ${ }^{14-18}$ of the fifteen materials reviewed were quantitative studies which used the survey method to collect data. The number of respondents for each study ranged between 36 and 1000 people. In these quantitative studies, the respondents were law enforcement officers, the general public, and university students. Survey questionnaires were either distributed directly to the respondents or via e-mail.

Five studies ${ }^{19-22}$ were qualitative. Semi-structured and in-depth interview, workshop, discussion, and documentation were the data collection methods that were adopted by these authors. The respondents for each research ranged between seven and 13 people. The respondents were government and private officials, and law enforcement officers. Lastly, studies Abdul ${ }^{23}$ (7594 respondents) and Rumaizah et a ${ }^{24}$ (124 respondents) and used a mixedmethod. Both quantitative and qualitative data collection methods such as survey, interviews, and focus group discussions were utilised by the respective authors.

\subsection{Anti-Corruption Strategies and Initiatives in Malaysia}

Five studies ${ }^{3,11-13,23}$, highlighted the numerous strategies and initiatives taken by the Malaysian government to eradicate corruption. Anti-corruption strategies and initiatives in Malaysia have been evidenced since the 1960's through efforts by the Anti-corruption Agency (ACA). In 1967, ACA was given the full authority by the government to carry out investigation, prevention, and prosecution of corruption cases in accordance with the Anti-Corruption Act 1967. The Anti-Corruption Act 1967 was later substituted by the National Bureau of Investigations (NBI) Act 1973, which was later replaced by the Anti-Corruption Act $1982^{25}$.

More recently, the Anti-Corruption Act 1982 was replaced with the MACC Act 2009; leading to the establishment of the MACC as an independent, transparent and professional body to eradicate all forms of corruption, abuse of power and malpractice ${ }^{25}$. Apart from the ACA, the Public Complaints Bureau (PCB) was formed to deliver a passive check on administration where the bureau receives and investigate complaints made by the public who are displeased with government administra$\operatorname{tion}^{13,26}$

The Auditor General's Office, Royal Malaysia Police (RMP), Attorney General's Office, Customs and Malaysian Administrative Modernisation, Public Accounts Committee, and Management Planning Unit (MAMPU) are the administrative and judicial institutions that are responsible to curb corruption and enhance integrity in the public sector. In the same way, Bank Negara Malaysia, Companies Commission, Ministry of Trade and Consumer Affairs, Bursa Malaysia, Malaysian Institute of Corporate Governance (MICG), Securities Commission, and Business Ethics Institute of Malaysia (BEIM) are responsible to combat corruption and pro- 
mote good governance and ethics in the private sector. In addition to these listed agencies, the Integrity Management Committees (IMC) was established to boost anti-corruption strategies at the various levels of government.

The National Integrity and Good Governance Department, Institute of Integrity Malaysia, and the Enforcement Agency of Integrity Commission also play significant roles in the government's anti-corruption goals. More recently, the Governance, Integrity and AntiCorruption Centre (GIACC) was established by the new ruling party (Pakatan Harapan) to oversee all matters related to governance, integrity, anti-corruption, and human rights ${ }^{27}$.

At the same time, various measures have been taken by the government to install positive values and work ethics among government officials. The measures that were expected to encourage positive values are Leadership by Example (1983), Name Tags (1985), Assimilation of Islamic Values (1985), Clean, Efficient and Trustworthy Government (1989), and Excellent Work Culture (1989). Similarly, quality of governance was expected to improve through Quality Control Circles, Total Quality Management, Clients Charter, ISO 9000 series and Benchmarking ${ }^{3,12,13}$. Lastly, the National Integrity Plan (NIP) and Islam Hadari framework were also introduced by the government to promote integrity and work ethics among all levels of the Malaysian society (Ibid).

In total, at least 18 agencies have been established and 12 strategies or programmes have been initiated in the past 60 years. None of the articles that were reviewed herein explained the pros and cons of each of the agencies and strategies or programmes. The importance of understanding the pros and cons of mechanisms and factors underlying corruption are that academicians and the public can perform balance and check measures on the effectiveness of the established agencies and strategies or programmes. This is significant so that the government can maximise the functions of agencies and strategies or programmes by eliminating weaknesses such as poor administrations, poor implementations strategies, and poor communication methods. Further, the evaluation of pros and cons can be used as evidence to abolish an agency and strategy or programme, and to establish a better one.

\subsection{Failures and Limitations of Government Anti-Corruption Efforts}

In this section, failures and limitations of anti-corruption efforts are discussed based on a review of the available literature. Several studies ${ }^{11-13,3}$ briefly explained the reasons behind the failures of anti-corruption actions in Malaysia. Two studies ${ }^{12,13}$ asserted major factors which lead to the failure. One of the factor poor implementation and subsequent consolidation of new models, institutions, and strategies in the Malaysian public sector. This poor implementation and patchwork have resulted in uncertainty among implementers, front line personnel and others within the organisational hierarchy as to which strategy to implement, who is responsible for the implementation, how to implement, process of knowledge transfer, and what outcomes to measure or monitor.

The second factor identified is the unwillingness of Malaysian leaders to fight political corruption, and the existences of institutions that are considered powerless and directly disrupt corruption initiatives by the government. It is likely that fear of work termination or job transfer may be behind the unwillingness of leaders to fight corruptions within their organisations. According to Noore $^{13}$, the third factor is defects in the country's political systems, cultures and institutions; that have led to failures of anti-corruption strategies. In fact, since the rise of $\mathrm{PH}$ into power, more than 17,000 political appointees have been planned for termination ${ }^{28}$ as their job descriptions are unclear yet they continue to reap benefits from government appointments. Ten government departments and agencies, and 19 other smaller divisions or offices under the Prime Minister's Office have been recently abolished due to redundant roles and being non-essential as means to reduce the government's debts incurred from corrupted practices ${ }^{29}$. In addition, five agencies have merged, and 40 agencies have been re-designated (Ibid).

Nur and $\mathrm{Nafsiah}^{3}$ cited the result of a study ${ }^{30}$ that revealed several reasons behind the ineffectiveness of government initiatives to curb corruption. The reasons are:the inability of the government to discourse the root cause of corruption, redundancies and duplications, and underwhelmed support from the public towards government efforts ${ }^{30}$.Moreover, people have lost confidence in the government's anti-corruption activities because of its poor response to serious corruption scandals involving the senior leaders of the ruling Barisan Nasional $(\mathrm{BN})^{3}$. 
Subsequently, in the 14th general election, Malaysians witnessed the fall and defeat of $\mathrm{BN}$, which had monopolized the politics in Malaysia for more than 60 years and ruled Malaysia since its independence in 1957. Over the years, dozens of corruption allegations involving the top political leaders from BN became a reason for many Malaysians to vote against $\mathrm{BN}$. One of the corruption allegations that has severely tarnished the BN's image is the $1 \mathrm{MDB}$ scandal ${ }^{31}$.

Money politics, the incapability of ACA to positively react on high profile corruption cases, tight state controls on media, Official Secrets Act that controls information access and disclosure of the government documents, and ethnic dimension of public policy and political patronage; are other reasons for widespread corruption and failures of anti-corruption acts ${ }^{3}$. It appeared that the government was promoting anti-corruption on one hand but on the other hand, rampant corruptions amongst high-ranking government personnel were not effectively addressed. Altogether, corruption has led to financial instability in Malaysia. Over the past 36 years, RM85.51 billion have been used from the taxpayers' funds to bail out troubled Government-Linked Companies (GLCs), such as Perwaja Steel, MAS, and $1 \mathrm{MDB}$ which were severely affected by the corruption ${ }^{32}$.

\subsection{Reasons Behind Corruption}

In this section, reasons behind corruption are reviewed. Four of the 15 materials reviewed herein investigated this element of the phenomenon. Rumaizah et $\mathrm{al}^{24}$ claimed that behavioural factors lead to corruption. Factors such as the desire to achieve a private or professional goal through corrupt action, subjective norms, Perceived Behavioural Control (PBC) and attitude are positively related to corrupt acts.

The authors also highlighted the core elements of corruption, that being mentality (lack of individual integrity), culture (cohesive set of ideas, belief, and knowledge), environment, lifestyle, and inevitability. Further, power (political, authority, and controlling), opportunity, and moral impurity are the reasons for corruption ${ }^{22}$.

More recently, study by Malini et $\mathrm{al}^{20}$ explored influences underlying corruption. The authors identified four categories of influences: family, public, individual, and organisational climate. Family influences such as children who are ill or being in critical condition, financial difficulties, love towards their family, pressure from the wife, and family needs or situations can lead to corruption.
The second category is public influence. Public influences include entertainment offers, attachment with negative peers, and comparison of lifestyle can influence a person to engage in corrupt acts too.

Next, individual influences such as belief, emotion, frustration, stress, and religious faith of a person can lead someone to engage in corruption. The fourth category is the behaviour of co-workers, organisational culture, and an environment tolerant of corruption. These factors underlie an organizational climate of corruption. Mohd ${ }^{15}$ added to this category of influence another type of influence, which is an economic influence. Economic factors also have a strong positive relationship in procurement corruption $^{15}$.

Most of the reasons in this section were listed and supported by western studies. Studies by western scholars demonstrated almost 17 reasons of corruption including: greed of money, power, luxury life or any other materialistic desires ${ }^{33}$, low levels of democracy, inefficient administrative and political structure ${ }^{34,35}$, weak civil participation $^{33,36}$, financial difficulties ${ }^{37,38}$, weak governmental structure and system ${ }^{39-41}$, and social influences ${ }^{42}$. Most of the local research articles covered sociological factors but none of the local research articles revealed in-depth explanation on psychological factors behind corruption. Only one study ${ }^{24}$ explained some behavioural factors underlying corruption, and as such more studies need to be done so that the phenomena of corruption can be better understood. This is important because knowledge from these researches can be adapted to form an effective and efficient strategy to curb corruption from the grassroots.

\subsection{The Prosecution in Bribery and Corruption Cases in Malaysia}

Other than the above aspects regarding corruption, one study ${ }^{21}$ examined corruption from the perspective of case prosecution. The study claimed that not everybody is equal in the eyes of the Malaysian judicial system when it comes to bribery and corruption cases. Unfairnes were identified by the authors in the fines and imprisonment of the offenders.

White collar workers, offenders who are politically connected, government servants, female offenders, indigenous Malaysians (Bumiputera) and private attorney offenders; receive less severe treatment compared to others ${ }^{21}$. 
Fines and imprisonments of offenders largely depend on prior criminal records and the seriousness of the offence. Aged offenders were punished with heavier fines but received lesser jail sentences compared to younger offenders. As a group, educated offenders receive more fines but fewer and shorter jail sentences ${ }^{21}$. To summarise, offenders' societal and political position, and power and personal characteristics; can influence the form and severity of punishments.

The study ${ }^{21}$ proved that the Malaysian judicial system is not as fair or independent as it should be. This is because sentencing decisions by the judges were easily influenced by the offender's societal and political position and power and personal characteristics. So, to uphold the public's confidence in the Malaysian judicial system an effective revamp needs to be done. Recently, the current $\mathrm{PH}$ government promised to perform a complete revamp of the country's judicial system, including the appointment of its top judges ${ }^{44,45}$.

\section{Conclusion}

The current $\mathrm{PH}$ government already starts to boost transparency, competency, and accountability by introducing the zero-based budgeting, the migration towards accrual accounting, embraced open tenders in the procurement process, improvement in the auditing reports, and institutional reforms. The successes from these strategies are evidenced when Malaysia rose one notch higher to 61 in The Corruption Index and achieved a 4th spot in market accountability and transparency. Technology and social media need to be utilised to the maximum to create awareness among the public regarding corruption and laws related to corruption, especially the Whistleblower Protection Act 2010.

A literature search from 2000 to 2017 did not provide any psychological and criminological studies of white collar crime offenders in Malaysia. Specifically, researches on people who have committed corruption are lacking. Researches need to be conducted to determine the psychological, criminogenic, and psychosocial characteristics such as criminal thinking styles, psychopathic traits, and personality traits of the offenders who have engaged in corruption. More in-depth analyses need to be carried out among white collar offenders beyond. The identification of socio demographic markers and motivations for criminal conduct; in order to understand the modus operandi and criminogenic sustaining factors. Such knowledge will provide more relevant information for crime prevention efforts.
Further, the understanding of specific characteristics in these profiles can improve our knowledge of rehabilitation needs of this population; particularly the combined criminogenic and psychological factors that underlie the actions of incarcerated white collar crime offenders in Malaysia. The knowledge herein may aid in the formation of a comprehensive rehabilitation module that is evidence-based and takes into consideration local contexts.

In addition, the outcomes of these psychological and criminological studies could advance evidence-based hiring practices. For example, traits that are related to workplace criminal behaviour can be identified. Subsequently, employers can use knowledge about those traits to develop a screening or monitoring assessment for employee selection. This has the potential to reduce opportunities for offending and reduce the likelihood of victimisation within organisations.

\section{References}

1. Malaysia Drops Two Points in Corruption Index. Date accessed: 25/02/2018. https://www.thestar.com.my/news/ nation/2018/02/22/malaysia-drops-two-points-in-corruption-index/.

2. Malaysia Drops to 62nd Position in 2017, it's Worst, in Corruption Perceptions Index. Date accessed: 22/02/2018. https://www.straitstimes.com/asia/se-asia/ malaysia-drops-to-62nd-position-in-2017-its-worst-incorruption-perceptions-index.

3. Nur SK, Nafsiah M. Insight of Anti-Corruption Initiatives in Malaysia, Procedia Economics and Finance. 2015; 31(15):525-34. https://doi.org/10.1016/S22125671(15)01197-1.

4. Malaysian Anti-Corruption Commission (MACC). What is corruption \& Statistics on arrest Date accessed: 2016. https://www.sprm.gov.my/index.php/en/education/whatis-corruption.

5. Merriam-Webster. Date accessed: 29/03/2019. https:// en.wikipedia.org/wiki/Merriam-Webster.

6. Frei C, Muethel M. Antecedents and consequences of MNE bribery: A multilevel review, Journal of Management Inquiry. 2017; 26(4):418-32. https://doi. org/10.1177/1056492617704305.

7. Types of False Claims Act Violations. Date accessed: 2018. https://www.kenneymccafferty.com/practice-areas/falseclaims-act/types-false-claims/.

8. More branded goods tendered as evidence at former Sports Ministry officer's trial. Date accessed: 21/06/2018. https:// www.nst.com.my/news/crime-courts/2018/04/358222/morebranded-goods-tendered-evidence-former-sports-ministry. 
9. Transparency International-Malaysia. Date accessed: 2017. http://transparency.org.my/.

10. Effective Health Care Data Extraction. Date accessed: 15/2/2019. https://www.slideshare.net/AHRQEHCProgram/ data-extraction

11. Nik RWA. Eradicating Corruption: The Malaysian experience, General Administration Department. 2008; 1(3):42-53.

12. Noore AS. Combating corruption and managing integrity in Malaysia: A critical overview of recent strategies and initiatives, Public Organization Review. 2010; 10(2):153-71. https://doi.org/10.1007/s11115-009-0102-y.

13. Noore AS. Approaches to fighting corruption and managing integrity in Malaysia : A critical perspective, Journal of Social and Administrative Sciences. 2011; 8(1):47-74.

14. Daily Lives and Corruption: Public Opinion in Malaysia. Date accessed: 2011. http://transparency.org.my/ laravel-filemanager/files/shares/2011-Corruption-Barometer-Malaysia.pdf.

15. Mohd NH. The Determinants of Public Procurement Corruption in Malaysia, World Applied Sciences Journal. 2016; 34(12):1865-88.

16. Nurul AZ, Wan MTWA, Nurul NA. Smart Governance Matrix (SGM) and corruption risk in Malaysia, International Journal of Business. 2015; 6(1):45-54.

17. Chong YW, Saari A. Exploring Malaysian business undergraduates' perceptions on managing corporate corruption, American Economic Journal. 2015; 5(2):95-97.

18. Duasa J. Tendency of corruption and its determinants among public servants: A case study on Malaysia, Munich Personal RePEc Archive. 2008; 1-16.

19. Khairul SAA, Alifah ALAR. E-Procurement: A tool to mitigate public procurement fraud in Malaysia? Electron J e-Government. 2015; 13(2):361-68.

20. Malini S, Zoharah O, Ismi A, Ramesh S. Exploring causes of bribery: A case study in a public organization in Malaysia, International Journal of Human Resource Studies. 2016; 6(3):1-16. https://doi.org/10.5296/ijhrs.v6i3.9812.

21. Punishment of bribery and corruption: Evidence from the Malaysian judicial system. Date accessed: 2017. http:// researcharchive.vuw.ac.nz/handle/10063/6867.

22. Zaleha O, Rohami S, Fathilatul ZAH. Corruption - Why do they do it? Procedia - Social and Behavioral Sciences. 2014; 164:248-57. https://doi.org/10.1016/j.sbspro.2014.11.074.

23. Abdul RE. Public Opinion Survey and Anti-Corruption Reform in Malaysia. In: 5th Regional Anti-corruption Conference. Beijing: ADB/OECD Anti-Corruption Initiative for Asia and the Pacific; 2005. p. 1-9.

24. Rumaizah MN, Roshana T, Abdul HN. Behavioural Factors of Corruption in the Construction Industry. In: Procedia Social and Behavioral Sciences; 2013. p. 64-74. https://doi. org/10.1016/j.sbspro.2013.11.008.
25. Organisation. Date accessed: 03/04/2019. https:// en.wikipedia.org/wiki/Organization.

26. Noore AS. Public accountability in Malaysia: Challenges and critical concerns, International Journal of Public Administration. 2005; 28(1-2):107-29. https://doi. org/10.1081/PAD-200044546.

27. Abu Kassim: New law to target 'wasteful' civil servants. Date accessed: 08/06/2018. https://www.freemalaysiatoday. com/category/nation/2018/06/08/abu-kassim-new-law-totarget-wasteful-civil-servants/.

28. 17,000 political appointees to be axed, says Dr Mahathir. Date accessed: 16/05/2018. https://www.nst.com.my/news/ nation/2018/05/370097/17000-political-appointees-beaxed-says-dr-mahathir.

29. The Star Online. Date accessed: 12/04/2019. https://www. thestar.com.my/.

30. Combatting corruption: Understanding anti-corruption initiatives in Malaysia. Date accessed: 2013. http://www. ideas.org.my/combatting-corruption-understanding-anticorruption-initiatives-in-malaysia/.

31. Royal rulers deplore Malaysia's "crisis of confidence. Date accessed: 07/10/2015. https://www.aljazeera.com/ news/2015/10/royal-rulers-deplore-malaysia-crisis-confidence-151007064312312.html.

32. How Malaysia Inc racked up RM85.5 billion losses. Date accessed: 01/04/2017. https://www.themalaysianinsight. $\mathrm{com} / \mathrm{s} / 1002$.

33. Dimant E, Tosato G. Causes and effects of corruption: What has past decade's empirical research taught us? A survey, Journal of Economic Surveys. 2018; 32(2):335-56. https://doi.org/10.1111/joes.12198.

34. Tanzi V. Corruption around the world corruption, Palgrave Macmillan Journals. 1998; 45(4):559-94. https://doi. org/10.2307/3867585.

35. Goel RK, Nelson MA. Causes of corruption: History, geography and government, Journal of Policy Modeling. 2010; 433-47. https://doi.org/10.1016/j.jpolmod.2010.05.004.

36. Bhattacharyya S, Hodler R. Media freedom and democracy in the fight against corruption, European Journal of Political Economy. 2015; 39:13-24. https://doi.org/10.1016/j.ejpoleco.2015.03.004.

37. Argandoña A. Private-to-private corruption, Journal of Business Ethics. 2003; 47(3):253-67. https://doi.org/10.1023/A:1026266219609.

38. Dincer OC, Gunalp B. Corruption, Income Inequality, and Poverty in the United States. In: 13th Coalition Theory Network Workshop; 2008. p. 1-38. https://doi.org/10.2139/ ssrn.1158446.

39. Fan CS, Lin C, Treisman D. Political decentralization and corruption: Evidence from around the world, Journal 
of Public Economics. 2009; 93(1-2):14-34. https://doi. org/10.1016/j.jpubeco.2008.09.001.

40. Sandholtz W, Koetzle W. Accounting for corruption: Economic structure, democratic norms, and trade, International Studies Quarterly. 1998; 44(1):31-50. https:// doi.org/10.1111/0020-8833.00147.

41. Dell'Anno R, Teobaldelli D. Keeping both corruption and the shadow economy in check: The role of decentralization, International Tax and Public Finance. 2015; 22(1):1-40. https://doi.org/10.1007/s10797-013-9298-4.

42. Dong B, Dulleck U, Torgler B. Conditional corruption, Journal of Economic Psychology. 2012; 33(3):609-27. https://doi.org/10.1016/j.joep.2011.12.001.
43. Affendy MA, Liew SW, Puah C. Common Indicators of Commercial Crime. In: 29th International Business Research Conference; 2014. p. 1-10.

44. Malaysia goes up one notch higher to 61 in corruption index. Read more at Date accessed: 28/04/2019. https:// www.thestar.com.my/news/nation/2019/01/29/malaysiagoes-up-one-notch-higher-to-61-in-corruption-index/.

45. Malaysia rises to 4 th spot for market accountability and transparency. Read more at Date accessed: 28/04/2019. https://www.nst.com.my/news/nation/2018/12/439473/ malaysia-rises-4th-spot-market-accountability-and-transparency. 